XIV. Évfolyam 2. szám - 2019. június

\title{
A XIII. HONVÉDELMI MINISZTÉRIUM FEJEZET SZEMÉLYI JUTTATÁSAINAK ÉS REÁLKERESETEINEK ALAKULÁSA A 2005- 2017. KÖZÖTTI IDŐSZAKBAN
}

\section{DEVELOPMENT OF PERSONAL ALLOWANCES AND REAL INCOMES IN THE BUDGETARY CHAPTER XIII. (MINISTRY OF DEFENCE) BETWEEN 2005 AND 2017}

\author{
KENESSEI Zsolt; PAP Andrea \\ (ORCID: 0000-0002-4048-755X); (ORCID: 0000-0003-3812-5864) \\ kenessei.zsolt@uni-nke.hu ; pap.andrea@uni-nke.hu
}

\begin{abstract}
Absztrakt
Az elmúlt néhány évben a XIII. Honvédelmi Minisztérium fejezetnél az állomány személyi juttatásai nagymértékben megnövekedtek. Köszönhető ez annak, hogy kormánydöntés alapján a katonák illetménye 2015 júliusában egy egyszeri átlagos $30 \%$-os, majd ezt követően 2019. január 01-jével bezárólag évente átlagosan bruttó $5 \%$-os mértékben emelkedett, a közalkalmazottak részére pedig a honvédelmi ágazati pótlék került bevezetésre. Ezekre azért volt szükség, mert egyrészt az utolsó jelentősebb bérfejlesztés 2005-2006-ban történt, másrészt a nemzetgazdaságban folyamatosan emelésre került a minimálbér és a garantált bérminimum, melynek következtében a fejezetnél dolgozók bére jóval elmaradt a civil munkaerőpiacon hasonló végzettséggel rendelkezö szakemberek jövedelmétöl. Cikkünkben azt vizsgáljuk meg, hogy hogyan alakultak a személyi juttatások és az átlagkeresetek 2005től 2017-ig nominál- és reálértékben, ha bázisnak a 2005-ös évet tekintjük.
\end{abstract}

Kulcsszavak: személyi juttatás, illetményfejlesztés, reálbér

\begin{abstract}
Over the past few years, regarding budgetary Chapter XIII. (Ministry of Defence) the personal allowances of the personnel increased greatly. This is due to the goverments decision, as part of the introduction of the new military carrer model, as of July 1, 2015 an average salary increase of $30 \%$ was implementedfor the soldiers, later on until January 1, 2019 there was an average of $5 \%$ increase every year. For the civil servants, the defence sector supplement was introduced. These were necessary because, on one hand, the last significant wage development occurred in 2005-2006, and on the other hand, the minimum wage and guaranteed minimum wage were constantly increased in the national economy, as a result of which the wage increase of the employees of the Chapter was much lower than that of professionals with similar qualifications in the civil labor market. In our article, we will look at how personal allowances and avrage earning developed from 2005 until 2017 in nominal and real value, using 2005 as base value.
\end{abstract}

Keywords: personal allowances, salary development, real wages 


\section{BEVEZETÉS}

2015-ben a katonák illetménye jelentősen megemelkedett. Ebben a cikkben azt vizsgáljuk meg, hogy az említett nagymértékü jövedelemnövekedés, amely az új katonai életpálya modell bevezetésének részét képezte, milyen változást okozott az egyes állománykategóriákban 2017ig. Azért csak eddig az időszakig, mert a 2018-as zárszámadás még nem áll rendelkezésre a publikáció elkészítésének idején.

Bemutatjuk, hogy 2005-2017. között hogyan alakultak a személyi juttatások a XIII. Honvédelmi Minisztérium fejezetnél (továbbiakban: HM fejezet), továbbá ezen belül a bruttó átlagkeresetek az egyes állománykategóriák esetében. A vizsgálat során a reálkeresetek kiszámításához a 2005-ös évet vettük alapul bázisnak, mégpedig azért, mert 2005-2011. között már analizálásra kerültek a jövedelmek ilyen formában egy disszertáció [1] keretében. Az adatok számításánál ugyanazt a módszertant használtuk fel, amely a doktori értekezésben is szerepelt, megteremtve ezáltal a folytonosságot és az összehasonlíthatóságot, továbbá az időbeli színvonal-változás irányát is meg tudjuk határozni az elemzés eredményeképpen.

\section{A SZEMÉLYI JUTTATÁSOK HELYZETE ÉS ALAKULÁSA}

Az elmúlt közel másfél évtizedben jelentős keresetnövekedés a katonaállomány tekintetében 2015. július 01-jén történt, amely átlagosan $30 \%$-os béremelést eredményezett. Természetesen 2005-2015. között is voltak emelések valamennyi állománykategóriában, de olyan kismértéküek, amelyek a fogyasztói árak növekedéséhez képest elenyészőnek tekinthetők. Arra voltunk kíváncsiak, hogy az időbeli színvonal-változás milyen irányban mozdult el 2005-2017. között. Ehhez meg kellett vizsgálnunk, hogy hogyan alakultak a személyi juttatások az elemzésként meghatározott időszakban.

A leíró statisztika eszköztárát felhasználva olyan mutatókat képeztünk, amelyek lehetővé teszik az összehasonlítást, valamint hozzájárulnak az időbeli színvonal-változás dinamikájának bemutatásához. Ilyenek például a dinamikus viszonyszámok közül a bázis- és láncviszonyszámok, továbbá az intenzitási viszonyszámok (fajlagos mutatók: 1 főre jutó személyi juttatás). A fogyasztóiár-index használatával kiszámított reálértékek alakulása (indexálás), valamint a trendvizsgálat, amelynek eredménye hozzájárul, hogy a jövőre nézve is következtetéseket vonjunk le.

A működési költségvetésből kiemelve, nominál- és reálértékben is megvizsgáltuk a személyi juttatások, mint kiemelt előirányzat teljesítéseit, amelyet a 1. táblázat és 1-2. ábrák foglalnak össze. 
KENESSEI; PAPP: A XIII. Honvédelmi Minisztérium fejezet személyi juttatásainak és reálkereseteinek...

\begin{tabular}{|c|c|c|c|c|c|c|c|c|c|}
\hline \multirow{2}{*}{ Év } & \multirow{2}{*}{ Létszám (fö) } & \multicolumn{3}{|c|}{ Személyi juttatás (eFt) } & \multirow{2}{*}{ Összesen } & \multirow{2}{*}{$\begin{array}{c}1 \text { före jutó személyi } \\
\text { juttatás összesen } \\
\text { (eFt/fö) }\end{array}$} & \multirow{2}{*}{$\begin{array}{c}\text { Változás } \\
\text { nominálértékben } \\
(2005=100 \%)\end{array}$} & \multirow{2}{*}{$\begin{array}{l}\text { Változás } \\
\text { reálértékben } \\
(2005=100 \%)\end{array}$} & \multirow{2}{*}{$\begin{array}{c}\text { Infláció } \\
(2005=100 \%)\end{array}$} \\
\hline & & HM & MH & $\begin{array}{c}\text { Egyéb } \\
\text { szervezetek }\end{array}$ & & & & & \\
\hline 2005 & 31394 & 16017,7 & 74480,7 & 16965,4 & 107463,8 & 3423 & 100,0 & 100,0 & 100,0 \\
\hline 2006 & 29180 & 13706,7 & 74002,1 & 17488,3 & 105197,1 & 3605 & 105,3 & 101,4 & 103,9 \\
\hline 2007 & 25776 & 14446,7 & 73551,0 & 18654,9 & 106652,6 & 4138 & 120,9 & 107,7 & 112,2 \\
\hline 2008 & 24944 & 13649,4 & 72117,9 & 20431,7 & 106199,0 & 4257 & 124,4 & 104,4 & 119,1 \\
\hline 2009 & 25904 & 13041,8 & 68110,9 & 19241,7 & 100394,4 & 3876 & 113,2 & 91,2 & 124,1 \\
\hline 2010 & 26692 & 12881,3 & 70040,4 & 19274,1 & 102195,8 & 3829 & 111,9 & 86,0 & 130,1 \\
\hline 2011 & 26292 & 12370,3 & 68147,0 & 18837,4 & 99354,7 & 3779 & 110,4 & 81,7 & 135,2 \\
\hline 2012 & 24540 & 9642,3 & 65494,8 & 17999,8 & 93136,9 & 3795 & 110,9 & 77,6 & 142,9 \\
\hline 2013 & 24461 & 7187,8 & 67263,3 & 18326,1 & 92777,2 & 3793 & 110,8 & 76,3 & 145,3 \\
\hline 2014 & 24043 & 7077,9 & 65799,4 & 19048,0 & 91925,3 & 3823 & 111,7 & 77,0 & 145,0 \\
\hline 2015 & 23729 & 8503,2 & 73621,6 & 20787,4 & 102912,2 & 4337 & 126,7 & 87,4 & 144,9 \\
\hline 2016 & 24083 & 9042,5 & 93398,4 & 23757,0 & 126197,9 & 5240 & 153,1 & 105,2 & 145,5 \\
\hline 2017 & 24928 & 9808,4 & 103702,0 & 27387,8 & 140898,2 & 5652 & 165,1 & 110,8 & 149,0 \\
\hline
\end{tabular}

1. táblázat. A személyi juttatások és a létszámok alakulása a vizsgált időszakban (a szerzők saját szerkesztése a [2] és a [3] alapján)

Az egy főre jutó személyi juttatások tekintetében 2008-ig növekedés, majd 2009-től egészen 2014-ig szinte minden évben csökkenés volt megfigyelhető, amely növekedés a kiadások emelkedésével és ezzel párhuzamosan a létszám csökkenésével, míg a csökkenés éppen az ellenkezőjével volt magyarázható. [1] 2015-töl a bérfejlesztésnek köszönhetően megindult egy erőteljes növekedés, amely legnagyobb arányban a 2016-os évet érintette, habár a vizsgálat 2017-ig történt (1. ábra), de az emelés 2019. január 01-jével fejeződött be, így hozzájárulva a személyi juttatások további növekedéséhez is.

Ha a nominálértékben történő változást vizsgáljuk, ugyanarra a következtetésre jutunk, mint az előző gondolat. A bázisévhez viszonyítva 2017-re nominálértékben 65,1 \%-os növekedés került kimutatásra. Azonban, ha a reálértékeket elemezzük, a változás 2005-höz képest 10,8 \%os növekedést mutat, amely az új életpálya modell bevezetéséhez kapcsolódó béremelésnek köszönhető, ami meghaladta az infláció mértékét, miközben 2013-ban már 22,4 \%-os csökkenést tapasztaltunk a bázishoz képest, amelyet az infláció hatása eredményezett. Ezt szemlélteti a 2. ábra is. 


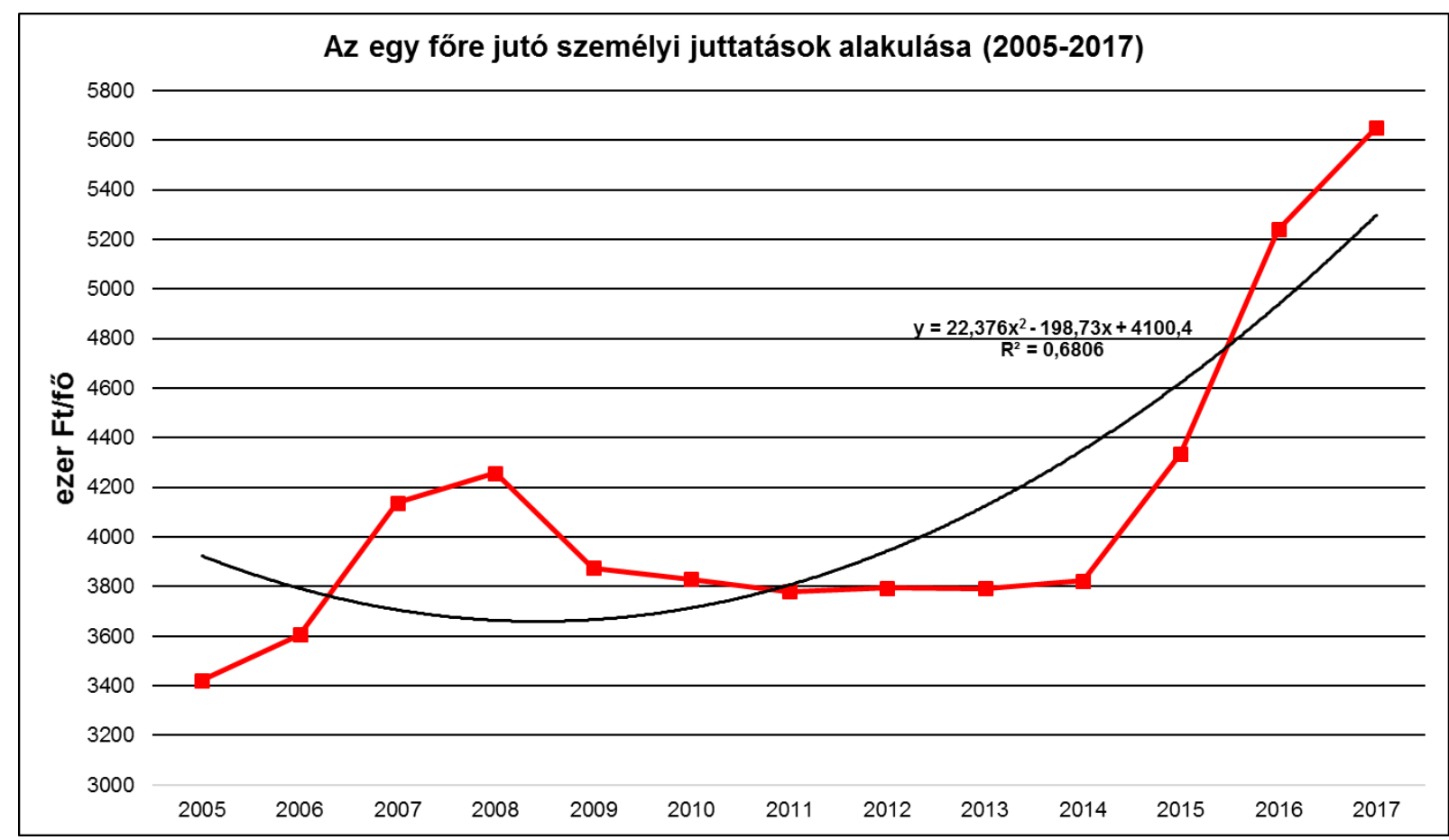

1. ábra Az egy főre jutó személyi juttatások alakulása (a szerzők saját szerkesztése a 1. táblázat alapján)

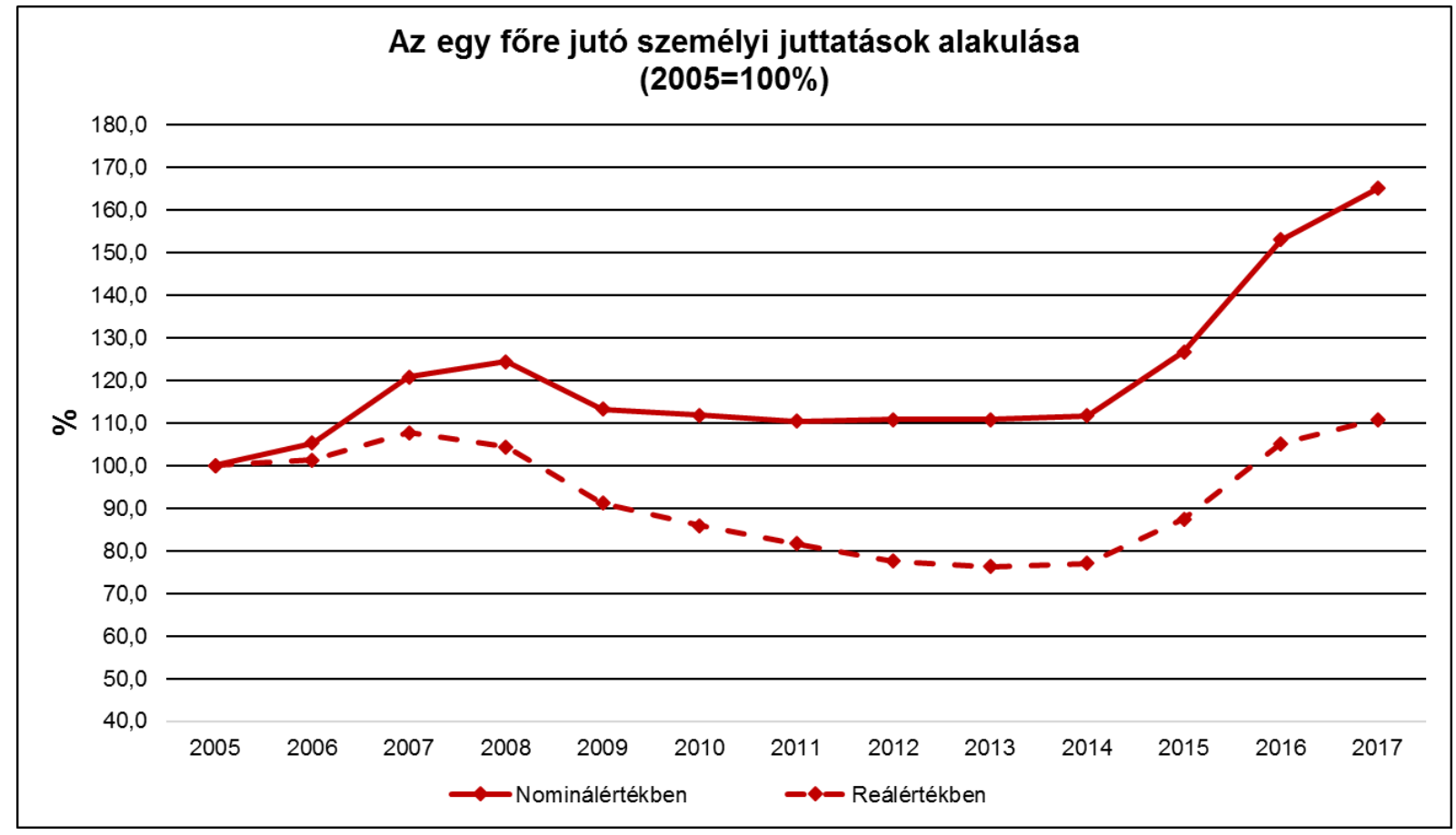

2. ábra Az egy főre jutó személyi juttatások alakulása nominál- és reálértékben (a szerzők saját szerkesztése a 1. táblázat alapján)

Megállapíhatjuk, hogy egy pozitív irányú időbeli színvonal-változás következett be 2005höz, majd egy viszonylagos stagnáló időszakhoz (2011-2014) képest is. A következő részben elemzésre kerülnek az egyes állománykategóriák jövedelmei és azok változásának okai a vizsgált időszakban. 


\section{A KERESETEK VÁLTOZÁSÁNAK HATÁSA A SZEMÉLYI JUTTATÁSOKRA}

A keresetek változása jelentős hatást gyakorolt a személyi juttatásokra, amelyet az mutat, hogy a nagyarányú létszámcsökkenés sem eredményezett a kiemelt elöirányzatban csökkenést (2-3. táblázat). Ugyanis az állomány nominálkeresete 2008-ig növekedett mindegyik állománykategóriában, amely nem csökkentette, hanem közel azonos szinten tartotta a személyi juttatások nagyságát, a létszámcsökkentések ellenére is. 2012-ben az 1 före jutó személyi juttatások csökkenéséhez az is hozzájárulhatott, hogy az ügyészség állománya átkerült másik tárcához. Mivel juttatásaik átlag felettiek voltak, azonban létszámuk igen alacsony, ebböl adódóan hatása nem tekinthető jelentős mértékünek. 2013-ban egy új állománykategória jelent meg, akik illetménye ugyan elmaradt az átlagtól, létszámuk is igen alacsony volt, de így is lefelé húzhatta az 1 főre jutó személyi juttatásokat. Hatása az előző kategóriához hasonlóan nem jelentős mértékü.

\begin{tabular}{|c|c|c|c|c|c|c|c|}
\hline \multirow[b]{2}{*}{ Év } & \multicolumn{7}{|c|}{ Bruttó nominál átlagkeresetek (Ft/fö/év) } \\
\hline & \begin{tabular}{|} 
Hivatásos \\
és \\
szerződéses \\
tiszt
\end{tabular} & $\begin{array}{c}\text { Hivatásos és } \\
\text { szerződéses } \\
\text { tiszthelyettes } \\
\text { (altiszt) }\end{array}$ & $\begin{array}{c}\text { Szerződéses } \\
\text { legénységi } \\
\text { állomány }\end{array}$ & $\begin{array}{c}\text { Köztisztviselő } \\
\text { (kormánytisztviselő) }\end{array}$ & Közalkalmazott & \begin{tabular}{|c|} 
Munakvállalók \\
(bírák, \\
ügyészek, \\
igazságügyi \\
alkalmazottak is \\
2011-ig) \\
\end{tabular} & $\begin{array}{c}\text { Munka } \\
\text { törvénykönyve } \\
\text { szerinti } \\
\text { munkavállaló }\end{array}$ \\
\hline 2005 & 4672308 & 2118540 & 1643664 & 4252956 & 1861332 & 3932544 & \\
\hline 2006 & 4923946 & 2296791 & 1855947 & 4622083 & 1968376 & 4197006 & \\
\hline 2007 & 5254941 & 2397114 & 1895546 & 5647390 & 2215290 & 4479105 & \\
\hline 2008 & 5539060 & 2630101 & 1981270 & 5928119 & 2452427 & 4825858 & \\
\hline 2009 & 5042942 & 2406930 & 1803707 & 5372335 & 2349031 & 4465335 & \\
\hline 2010 & 4984270 & 2428998 & 1818958 & 4978995 & 2277602 & 4451855 & \\
\hline 2011 & 4923070 & 2321384 & 1728721 & 4284223 & 2177246 & 4568755 & \\
\hline 2012 & 4915468 & 2426114 & 1825939 & 4462881 & 2380951 & & \\
\hline 2013 & 4889193 & 2499358 & 1912161 & 4389356 & 2524092 & & 2040391 \\
\hline 2014 & 4918939 & 2599649 & 1965747 & 4589414 & 2633887 & & 2169706 \\
\hline 2015 & 5426213 & 3220472 & 2442197 & 4618199 & 2487255 & & 1786000 \\
\hline 2016 & 6417890 & 4507851 & 3445430 & 4760922 & 2737528 & & 2156022 \\
\hline 2017 & 6743911 & 4747732 & 3906115 & 4810981 & 3115093 & & 2006928 \\
\hline
\end{tabular}

2. táblázat A bruttó átlagkeresetek nominálértékben (a szerzők saját szerkesztése a [2] alapján)

\begin{tabular}{|c|c|c|c|c|c|c|c|c|}
\hline \multirow[b]{2}{*}{ Év } & \multicolumn{7}{|c|}{ Bruttó reál átlagkeresetek (Ft/fó/év) (2005. évi áron) } & \multirow[b]{2}{*}{$\begin{array}{c}\text { Infláció } \\
(2005=100 \%)\end{array}$} \\
\hline & $\begin{array}{c}\text { Hivatásos és } \\
\text { szerződéses tiszt }\end{array}$ & $\begin{array}{l}\text { Hivatásos és } \\
\text { szerzödéses } \\
\text { tisthelyettes } \\
\text { (altiszt) }\end{array}$ & $\begin{array}{c}\text { Szerződéses } \\
\text { legénységi } \\
\text { állomány }\end{array}$ & $\begin{array}{c}\text { Köztisztviselö } \\
\text { (kormánytisztviselő) }\end{array}$ & Közalkalmazott & $\begin{array}{c}\text { Munakvállalók } \\
\text { (bírák, ügyészek, } \\
\text { igazságügyi } \\
\text { alkalmazottak is } \\
\text { 2011-ig) }\end{array}$ & $\begin{array}{c}\text { Munka } \\
\text { törvénykönyve } \\
\text { szerinti } \\
\text { munkavállaló }\end{array}$ & \\
\hline 2005 & 4672308 & 2118540 & 1643664 & 4252956 & 1861332 & 3932544 & & 100,0 \\
\hline 2006 & 4739120 & 2210578 & 1786282 & 4448588 & 1894491 & 4039467 & & 103,9 \\
\hline 2007 & 4683548 & 2136465 & 1689435 & 5033324 & 1974412 & 3992072 & & 112,2 \\
\hline 2008 & 4650764 & 2208313 & 1663535 & 4977430 & 2059133 & 4051938 & & 119,1 \\
\hline 2009 & 4063612 & 1939508 & 1453430 & 4329037 & 1892853 & 3598175 & & 124,1 \\
\hline 2010 & 3831107 & 1867024 & 1398123 & 3827052 & 1750655 & 3421872 & & 130,1 \\
\hline 2011 & 3641324 & 1717000 & 1278640 & 3168804 & 1610389 & 3379257 & & 135,2 \\
\hline 2012 & 3439796 & 1697770 & 1277774 & 3123080 & 1666166 & & & 142,9 \\
\hline 2013 & 3364895 & 1720136 & 1316009 & 3020892 & 1737159 & & 1404261 & 145,3 \\
\hline 2014 & 3392372 & 1792861 & 1355688 & 3165113 & 1816474 & & 1496349 & 145,0 \\
\hline 2015 & 3744798 & 2222548 & 1685436 & 3187163 & 1716532 & & 1232574 & 144,9 \\
\hline 2016 & 4410921 & 3098179 & 2367993 & 3272111 & 1881463 & & 1481802 & 145,5 \\
\hline 2017 & 4526115 & 3186397 & 2621554 & 3228846 & 2090666 & & 1346932 & 149,0 \\
\hline
\end{tabular}

3. táblázatA bruttó átlagkeresetek reálértékben (a szerzők saját szerkesztése a [2] és a [3] alapján) 
KENESSEI; PAPP: A XIII. Honvédelmi Minisztérium fejezet személyi juttatásainak és reálkereseteinek...

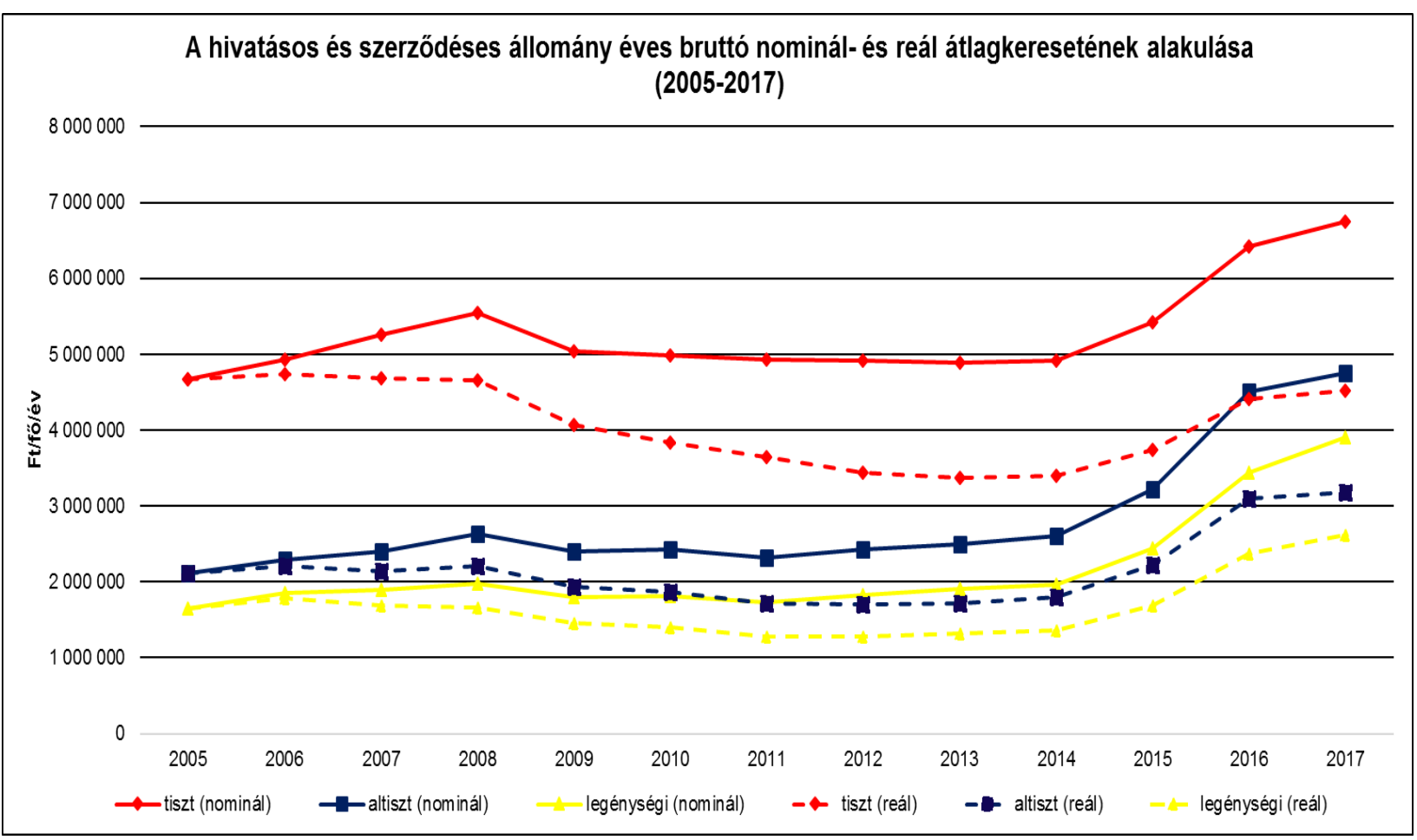

3. ábra A hivatásos és a szerződéses állomány éves bruttó nominál- és reál átlagkeresetének alakulása (a szerzők saját szerkesztése a 2. és a 3. táblázat adatai alapján)

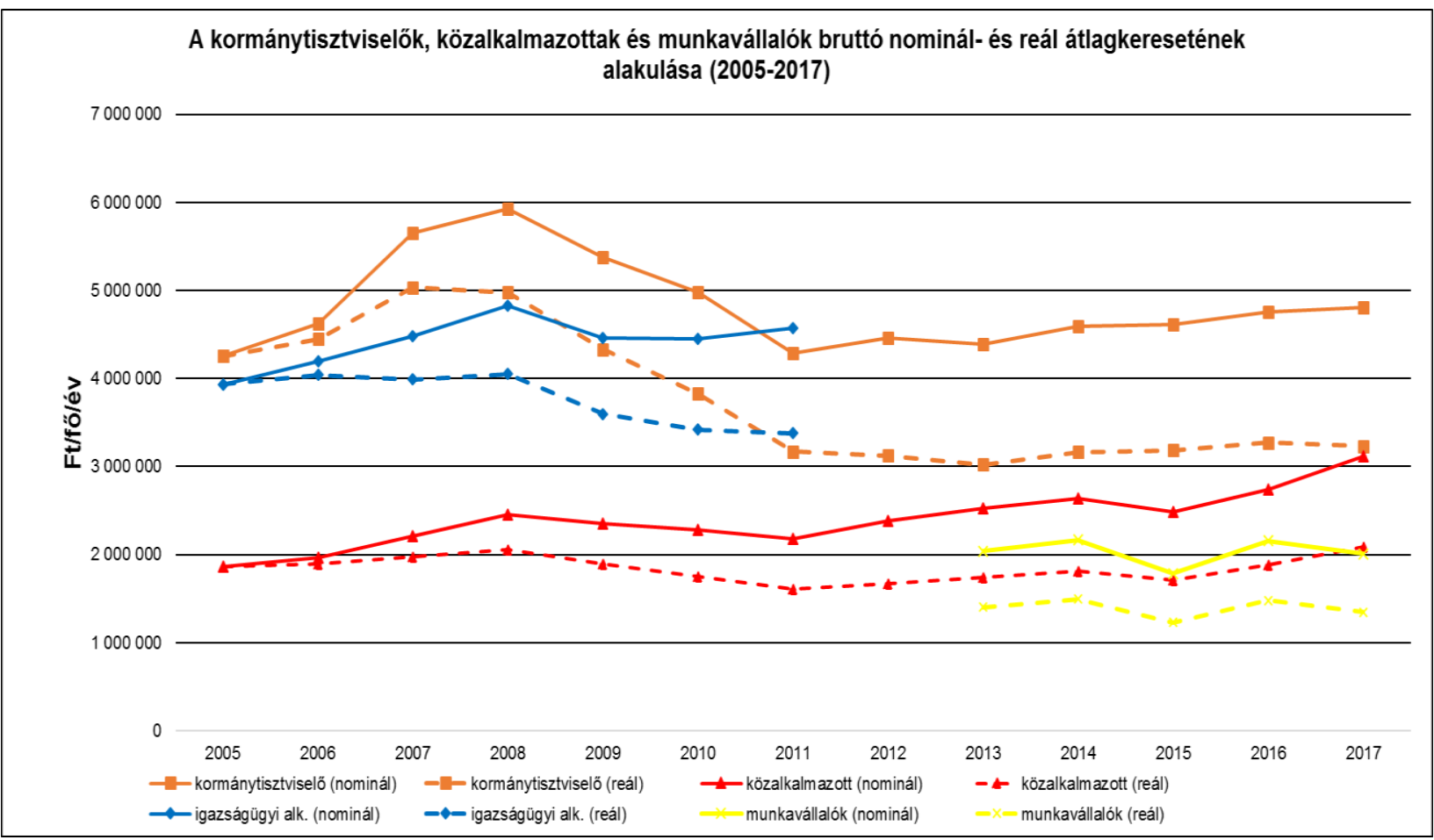

4. ábra A kormánytisztviselők, a közalkalmazottak és a munkavállalók bruttó nominál- és reál átlagkeresetének alakulása (a szerzők saját szerkesztése a 2. és a 3. táblázat adatai alapján)

Megvizsgáltuk, hogy évente, melyek voltak azok a lényeges tényezők, amelyek a legnagyobb hatást gyakorolták a személyi juttatásokra a jövedelmek változásán (növekedés, csökkenés) keresztül. Ezek a következők: 
- 2005-ben a hivatásos és szerződéses állomány, valamint a köztisztviselők átlagosan $6 \%$-os, továbbá a közalkalmazottak (továbbiakban: ka.) $4 \%$-os béremelése és a tervezett 13. havi illetmény kifizetése;

- 2006-ban az átlagos 5 \%-os béremelés és az egyes katonai szervezetek magasabb illetménykiegészítési kategóriába történő átsorolása;

- 2007-ben a 13. havi illetmény-előleg 6/12-ed részének kifizetése, illetménykiegészítés növekedése magasabba sorolás következtében, személyi állomány átvétele miatti bérkülönbözetek kiegyenlítése, valamint mérséklése;

- 2008-ban a 6 heti illetmény-elöleg kifizetése, a hivatásos és szerződéses állomány részére bevezetésre kerülő szolgálati időpótlék, valamint a létszámhiány miatt kifizetett megbízási, túlszolgálati, illetve helyettesítési díjak, továbbá a ka. állomány esetén az illetménynövekedés oka a HM Állami Egészségügyi Központ ka-ainak illetménykorrekciója;

- 2009-ben a HM fejezet átlagában 8,1 \%-kal csökkentek az átlagkeresetek - a 13. havi illetmény nem került kifizetésre -, miközben a köztisztviselői illetményalap, az ügyészi alapilletmény, a közalkalmazotti illetménytábla és a pótlékalap változatlan maradt, azonban kompenzálásként a teljes állomány részesült kereset-kiegészítésben az első félévben, míg a második félévben ez már csak egyes kategóriáknak volt finanszírozható a törvényi változások miatt, továbbá az eddig fizetett plusszmunka ellentételezésekénti díj is limitálásra került a második félévre;

- 2010-ben általánosságban az alapok nem változtak 2009-hez képest, azonban összességében csökkenés - függetlenül attól, hogy egyes kategóriákban emelkedett, másokban csökkent az átlagkereset - volt, mégpedig amiatt, hogy az előző évi kereset-kiegészítés rendszere megváltozott;

- 2011-ben miközben az illetményalap, az illetménytábla és a pótlékalap az előző évihez képest nem változott, mégis egyes kategóriákban csökkenés, míg másokban növekedés volt, összességében azonban csökkenés mutatható ki, amely egyrészröl a kereset-kiegészítés megszünésének, másrészről a törvényi változásoknak tudható be;

- 2012-ben az előző évihez képest az alapok nem változtak, de a tisztek esetében csökkent a kereset (a tisztek kiválása miatt), a többi állománykategóriánál nőtt, összességében növekedett, amely a kereset kompenzáció további folyósításának köszönhetö;

- 2013-ban a 2012-es évhez hasonlóan az alapokban nem történt változás, miközben a keresetek a kormánytisztviselőknél és a tiszteknél tovább csökkentek (kiválás miatt), a ka-nál az egészségügyi dolgozók illetményének köszönhetően, míg az altiszti és a szerződéses legénységi állománynál a kifizetett túlszolgálati és készenléti díjak miatt volt növekedés;

- 2014-ben az eddigiekhez hasonlóan az alapok változatlanok maradtak, azonban valamennyi állománykategóriánál nőttek az illetmények, az altiszti és a szerződéses legénységi állomány részére kiegészítő juttatásként $10000 \mathrm{Ft} / \mathrm{hó} / \mathrm{fő}$ került biztosításra, más állománykategória esetében a törvényi változások hatása miatt következett be a növekedés;

- 2015-ben az előző évhez viszonyítva a tárgyévben a köztisztviselői illetményalap, a közalkalmazotti illetménytábla és pótlékalap nem emelkedett, viszont a Kormány döntése értelmében a katonáknál július 01-jei hatállyal átlagosan $30 \%$ \%-os illetményfejlesztés került végrehajtásra, míg a közalkalmazottak esetében bevezetésre került a honvédelmi ágazati pótlék (2015. 07. 01-jétől $8450 \mathrm{Ft} /$ hó), ezen törvényi kereteken túl is emelkedtek az illetmények, mégpedig azért, mert a határmenti feladatok ellátásába bevont állomány részére túlóra és egyéb pótlékok kerültek kifizetésre; 
- 2016-ban az alapok az előző évekhez hasonlóan nem változtak, azonban január 01jével a katonaállomány esetében tovább folytatódott az illetményfejlesztés, így átlagosan $5 \%$-kal nőttek a bérek, a ka-nál pedig az ágazati pótlék összegének változása (16 900 Ft/hó) eredményezett növekedést. Az egészségügyben dolgozók bérfejlesztése is megtörtént, továbbá a legénységi állományú katonáknál bevezetésre került a munkaerö-piaci pótlék, valamint a törvényi kereteken túl is történt kereset növekedés az elöző évhez hasonlóan;

- 2017-ben csak annyi változás történt, hogy a szerződéses legénységi állomány, valamint a nem a Nemzeti Egészségbiztosítási Alapkezelő (továbbiakban: NEAK) által finanszírozott egészségügyi dolgozók részére bevezették a kiegészítő illetményt, illetve befolyásolta még a keresetek alakulását a kötelező legkisebb munkabér (minimálbér) és a garantált bérminimum jelentős emelkedése is. [2]

A táblázatok és az ábrák adataiból az is látszik, hogy 2012-2013-ban változás következett be egyes állománykategóriákban, amelynek az oka az volt, hogy 2012-től a Katonai Ügyészség személyi állománya átadásra került a Magyar Köztársaság (Magyarország) ügyészi szervezetébe. 2013-tól a szervezeti korszerüsítés következtében a visszavett rekreációs tevékenység elvégzése érdekében egy új állománykategória került bevezetésre, mégpedig a munkavállaló.

A 3-4. ábrákból az is kitünik, hogy 2009-töl csökkenés következett be valamennyi állománykategória esetében nominál- és reálkeresetben egyaránt. 2012-től 2014-ig egy viszonylagos stagnálás mutatkozott mind a személyi juttatásokban, mind pedig az átlagkeresetekben, majd 2015-töl egy eröteljes növekedés figyelhető meg. Ezek okai a fentebb említettekre vezethetők vissza. A vizsgált időszakban a legnagyobb mértékü emeléshez nominál- és reál átlagkereset tekintetében is az altiszti és a szerződéses legénységi állomány jutott.

Összességében tehát elmondható, hogy az időbeli színvonal-változás pozitív irányú volt nominál- és reál átlagkeresetek tekintetében egyaránt, de ha nem lett volna a 2015. évi életpálya modell bevezetés, akkor az átlagkeresetek nominálértékü stagnálása, vagy minimális arányú növekedése folytatódott volna tovább, reálértékben pedig további csökkenés lett volna megfigyelhető 2005-höz képest szinte valamennyi állománykategória esetében.

A kapott eredmények után kíváncsiak voltunk arra is, hogy a nemzetgazdasági átlagkeresetekhez képest hogyan alakultak a fejezet keresetei, amelyet a következő fejezetben mutatunk be.

\section{A NEMZETGAZDASÁG ÉS A FEJEZET ÁTLAGKERESETEINEK ÖSSZEHASONLÍTÁSA}

Az elöző részben kimutattuk, hogy a XIII. Honvédelmi Minisztérium fejezetnél az átlagkeresetek nominál- és reálértékben is emelkedtek 2005-höz képest, de célszerü ezt a nemzetgazdaság adataival is összehasonlítani. Ezt mutatja be a 4. táblázat és az 5. ábra. A tárcánál az éves adatok kiszámításához nem a súlyozott adatok kerültek figyelembe vételre, hanem az éves jövedelmek egyszerü számtani átlagát határoztuk meg, mivel az állománykategóriánkénti létszámadatok nem álltak rendelkezésre. 
KENESSEI; PAPP: A XIII. Honvédelmi Minisztérium fejezet személyi juttatásainak és reálkereseteinek...

\begin{tabular}{|c|c|c|c|c|c|c|c|}
\hline Év & $\begin{array}{c}\text { Nominál éves bruttó } \\
\text { átlagkereset a } \\
\text { nemzetgazdaságban } \\
\text { (Ft/fó) }\end{array}$ & $\begin{array}{c}\text { Nominál éves bruttó } \\
\text { átlagkereset a } \\
\text { fejezetnél (Ft/fó) }\end{array}$ & $\begin{array}{c}\text { Infláció } \\
(2005=100 \%)\end{array}$ & $\begin{array}{c}\text { Változás } \\
\text { nominálértékben a } \\
\text { nemzetgazdaságban } \\
(2005=100 \%) \\
\end{array}$ & \begin{tabular}{|c|} 
Változás \\
nominálértékben a \\
fejezetnél \\
$(\mathbf{2 0 0 5}=\mathbf{1 0 0 \% )}$ \\
\end{tabular} & \begin{tabular}{|c|} 
Változás \\
reálértékben a \\
nemzetgazdaságban \\
$(2005=100 \%)$ \\
\end{tabular} & $\begin{array}{c}\text { Változás } \\
\text { reálértékben a } \\
\text { fejezetnél } \\
(\mathbf{2 0 0 5}=\mathbf{1 0 0 \% )}\end{array}$ \\
\hline 2005 & 1900116 & 3080224 & 100,0 & 100,0 & 100,0 & \begin{tabular}{|r|}
100,0 \\
\end{tabular} & 100,0 \\
\hline 2006 & 2056212 & 3310692 & 103,9 & 108,2 & 107,5 & 104,2 & 103,4 \\
\hline 2007 & 2220204 & 3648231 & 112,2 & 116,8 & 118,4 & 104,1 & 105,6 \\
\hline 2008 & 2387568 & 3892806 & 119,1 & 125,7 & 126,4 & 105,5 & 106,1 \\
\hline 2009 & 2398044 & 3573380 & 124,1 & 126,2 & 116,0 & 101,7 & 93,5 \\
\hline 2010 & 2430300 & 3490113 & 130,1 & 127,9 & 113,3 & 98,3 & 87,1 \\
\hline 2011 & 2557128 & 3333900 & 135,2 & 134,6 & 108,2 & 99,5 & 80,1 \\
\hline 2012 & 2676720 & 3202271 & 142,9 & 140,9 & 104,0 & 98,6 & 72,8 \\
\hline 2013 & 2768568 & 3042425 & 145,3 & 145,7 & 98,8 & 100,3 & 68,0 \\
\hline 2014 & 2852340 & 3146224 & 145,0 & 150,1 & 102,1 & 103,5 & 70,4 \\
\hline 2015 & 2975088 & 3330056 & 144,9 & 156,6 & 108,1 & 108,1 & 74,6 \\
\hline 2016 & 3158052 & 4004274 & 145,5 & 166,2 & 130,0 & 114,2 & 89,3 \\
\hline 2017 & 3564204 & 4221793 & 149,0 & 187,6 & 137,1 & 125,9 & 92,0 \\
\hline
\end{tabular}

4. táblázat A nemzetgazdaság és a fejezet éves átlagkereseteinek összehasonlítása (a szerzők saját szerkesztése a [2], a [3] és a [4] alapján)

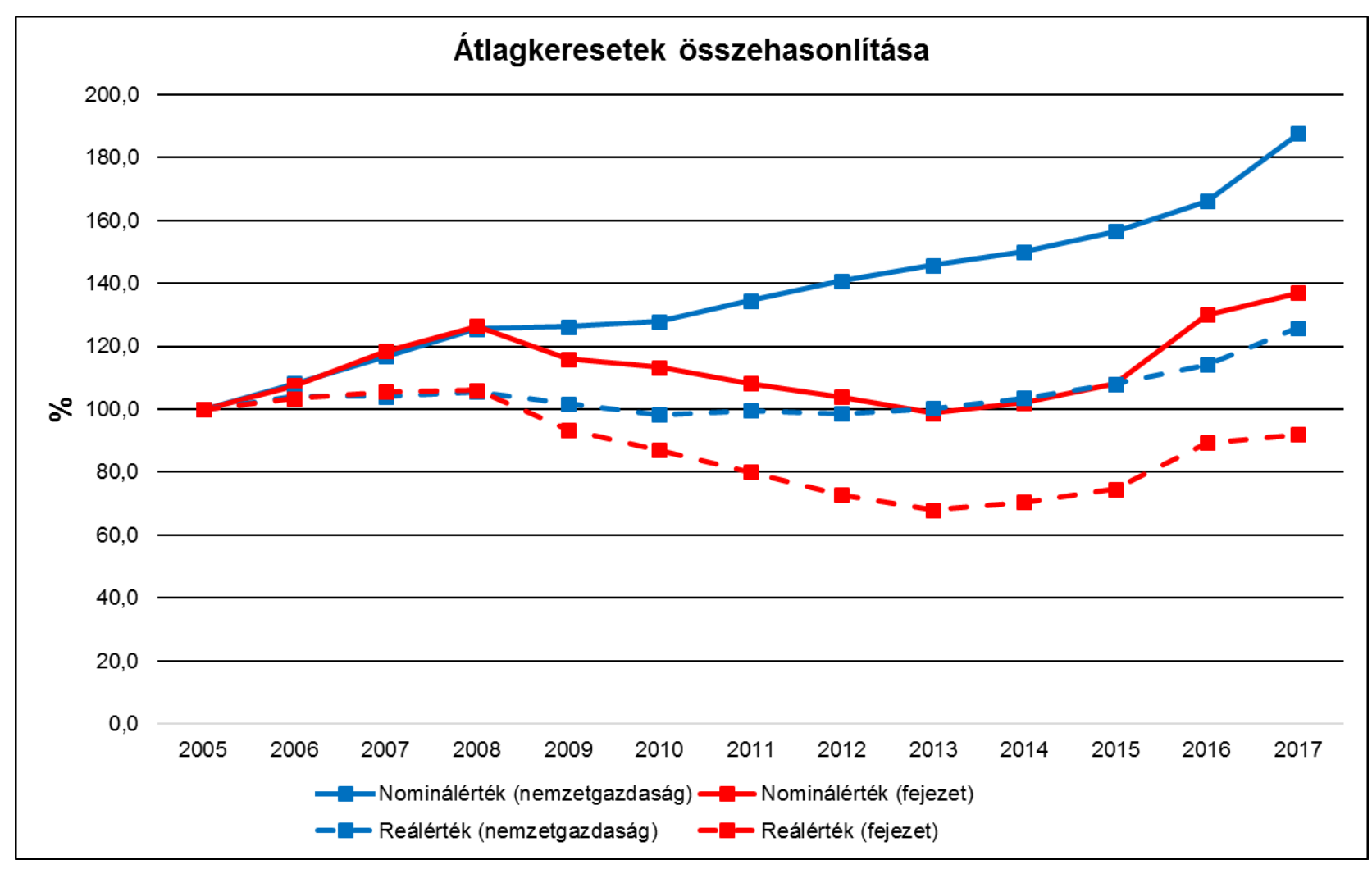

5. ábra Átlagkeresetek összehasonlítása (a szerzők saját szerkesztése a 4. táblázat alapján)

A nemzetgazdaság és a fejezet átlagkereseteinek összehasonlítása során kimutattuk azt, hogy ha csak a fejezet jövedelmeit vizsgáljuk, akkor jónak tekinthető a növekedés, azonban, ha a nemzetgazdasággal hasonlítjuk össze az emelkedéseket, már nem mondható el ugyanez. A kapott eredményeket elemezve a nemzetgazdaságban nominálértékben $87 \%$-os, ezzel szemben a fejezetnél mindössze $37 \%$-os növekedést, reálértékben az elöbbinél $26 \%$-os növekedést, míg az utóbbinál $8 \%$-os csökkenést tapasztaltunk. A táblázat adataiból is látszik, hogy a nemzetgazdaságban nominálértékben közel 50 \%-kal, míg reálértékben majdnem 34 \%-kal volt nagyobb a növekedés a fejezethez képest ugyanazon időszak alatt. Tehát, amíg a tárca mutatóit önmagukban jónak ítéltük meg, addig összevetve a nemzetgazdaság adataival már árnyaltabb képet mutatnak. Ez azt is jelentheti, hogy nem véletlenül történhettek létszámcsökkenések a 
fejezetnél, hiszen a nemzetgazdaság más szektoraiban több jövedelmet kaptak a foglalkoztatottak, mint itt. Ezáltal a tárca munkaerőpiaci vonzereje csökkent.

\section{ÖSSZEGZÉS}

A leíró statisztika eszköztárát alkalmazva olyan mutatókat képeztünk és használtunk fel, amivel képesek voltunk bebizonyítani azt, hogy az átlagkeresetek és ezzel összefüggésben a személyi juttatások pozitív irányú színvonal-változása következett be a vizsgált 13 év alatt, függetlenül attól, hogy voltak csökkenések és stagnálások. Azonban az utolsó fejezetben történt összehasonlítás azt is bebizonyította, hogy amit mi jónak véltünk, már kevésbé tekinthető annak, hiszen a nemzetgazdasági átlagkeresetek növekedése jóval meghaladta a fejezetnél tapasztalható változást. Továbbá megállapítható az is, hogy a kormányzati döntések nagyban befolyásolják a jövedelmek alakulását pozitív és negatív irányban egyaránt, amelyet alátámaszt a 2015-ös új katonai életpálya modell bevezetése, vagy a 13. havi illetmény eltörlése.

\section{FELHASZNÁLT IRODALOM}

[1] Pap Andrea örnagy: A Honvédelmi Minisztérium gazdálkodásának aspektusai a 20052011. közötti időszakban doktori (PhD) értekezés, Nemzeti Közszolgálati Egyetem, Hadtudományi Doktori Iskola, Budapest, 2013.

[2] Szöveges beszámoló jelentés a XIII. Honvédelmi Minisztérium fejezet 2005., 2006., 2007., 2008., 2009., 2010., 2011., 2012., 2013., 2014., 2015., 2016. és 2017. évi költségvetésének teljesítéséröl

[3] https://www.ksh.hu/docs/hun/xstadat/xstadat_eves/i_qsf001.html letöltve: 2019.03.08.

[4] https://www.ksh.hu/docs/hun/xstadat/xstadat_hosszu/h_qli001.html letöltve: 2019.06.05. 